\title{
TINJAUAN MEKANISME KONTRAK PENGELOLAAN LAHAN PERTANIAN BERBASIS ADAT ISTIADAT DALAM KAJIAN FIQH MUAMALAH (DESA TEMU, KECAMATAN KANOR, KABUPATEN BOJONEGORO) ${ }^{11}$
}

\author{
Beny Septyliyan Primada \\ Mahasiswa Program Studi S1 Ekonomi Islam-Fakultas Ekonomi dan Bisnis-Universitas Airlangga \\ Email : benma96@gmail.com
}

Irham Zaki

Departemen Ekonomi Syariah-Fakultas Ekonomi dan Bisnis-Universitas Airlangga Email : irhamzaki@gmail.com

\begin{abstract}
:
This study aims to identify and explain the suitability of the system or how cooperation cultivation of agricultural land undertaken Muslim farmers in the village of Temu, Kanor, Bojonegoro which has been run for generations by way of cooperation cultivation of agricultural land in Islam or figh kaedah muamalah.

Results of this study indicate that there are conformity system or way of cooperation cultivation of agricultural land that the farmers in the village Temu (anvil) with kaedah muamalah Islamic figh, because it has met the conditions prevailing in harmony and with both sides to contain the principle that there is an element of mutual muamalah willing and mutually their benefits, as well as a custom ('urf) that do not conflict with the texts of the Qur'an and the Hadith, and also does not contain madharat.
\end{abstract}

Keywords: Fiqh Muamalah, Agriculture, Muslim Farmers, 'Urf

\section{PENDAHULUAN}

\section{Latar Belakang}

Kekayaan hayati dan Sumber Daya Manusia di Indonesia membuat Negara Indonesia cocok dalam bidang pembangunan pertanian yang tidak banyak dimiliki oleh Negara lain. (Sukino, 2013: 6). Jumlah petani di Indonesia menurut Badan Pusat Statistik atau BPS (2014) pada tahun 2013 sebesar 31.705.337 jiwa. Tetapi kemiskinan masyarakat desa yang mayoritas bermata pencaharian sebagai petani masih sangat tinggi. Ada banyak faktor yang menyebabkan masyarakat petani masih terus terbelenggu dengan kemiskinan. Faktor alam yang tidak menentu seperti cuaca dan iklim menyebabkan proses

1) Jurnal ini merupakan bagian dari skripsi yang ditulis oleh Beny Septyliyan Primada, NIM : 041014024 , yang diuji pada 07 Agustus 2015. tanam menjadi terganggu. Tentunya semua itu sebab akibat oleh tangantangan manusia sendiri yang membuat keseimbangan alam menjadi terganggu. Industri yang berlebihan tanpa menghiraukan dampak lingkungan mengakibatkan global warming. Sikap tidak puas oleh masyarakat dengan hasil panen yang kurang memuaskan menyebabkan pemakaian pupuk kimia yang berlebihan justru menyebabkan kesuburan tanah terganggu dan menyebabkan hasil panen menjadi menurun.

Selain itu dukungan dan perhatian pemerintah yang kurang masih membuat masyarakat mengolah lahan pertanian 
dengan cara tradisional dan penggunaan teknologi masih rendah sehingga juga menyebabkan tingkat kemiskinan masyarakat petani masih relatif tinggi. Hal ini juga diperparah dengan semakin bertambahnya penduduk Indonesia yang menyebabkan lahan pertanian menjadi berkurang karena lahan pertanian berubah menjadi tempat pemukiman. Lahan pertanian yang diwariskan ke anak cucu terbagi-bagi menjadi kecil sehingga lahan yang di garap oleh setiap petani menjadi sempit dan hasilnya tidak bisa mencukupi kebutuhannya. Ini terlihat bahwa petani gurem atau petani dengan luas lahan kurang dari 0,5 hektar memiliki prosentase $54 \%$ dan petani yang tidak memiliki lahan atau hanya sebagai buruh tani memiliki prosentase $27 \%$ (data BPS 2013). Belum lagi dengan kurangnya proteksi dari pemerintah terhadap petani sehingga para tengkulak dengan mudah dapat mempermainkan harga yang menyebabkan para petani kembali menjadi korban.

Di sisi lain sistem kapitalis sejak Belanda mulai menjajah Indonesia hingga sekarang memberikan pengaruh besar terhadap sistem perekonomian dan pertanian di Indonesia yang telah menggusur nilai-nilai budaya, sosial dan keagamaan dalam kehidupan. Sikap jujur dan tolong menolong yang terkandung dalam nilai-nilai budaya, sosial dan keagamaan telah terkikis oleh alasan ekonomi. Sifat individualis saat ini mulai tertanam kuat di dalam pola pikir masyarakat Indonesia. Padahal Indonesia merupakan negara yang memiliki penduduk beragama Islam terbesar di dunia. Dan Allah SWT pun telah berfirman untuk saling tolong-menolong dalam kebaikan. Firman Allah SWT dalam QS. AImaidah ayat 2 :

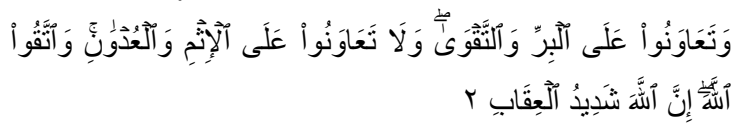

Wata'awanu 'alalbirri waattaqwa wala ta'awanu 'alal ithmi waal'udwani wattaqu Allaha inna Allaha shadiidul'iqabi Artinya :Dan tolong-menolonglah kamu dalam (mengerjakan) kebajikan dan takwa, dan jangan tolong-menolong dalam berbuat dosa dan pelanggaran. Dan bertakwalah kamu kepada Allah, sesungguhnya Allah amat berat siksaNya.(QS. Al-maidah:2)

Salah satu filosofi dasar ajaran Islam dalam kegiatan ekonomi dan bisnis (pertanian), yaitu larangan untuk berbuat curang dan dzalim. Semua transaksi yang dilakukan oleh seorang muslim haruslah berdasarkan prinsip rela sama rela (an taradin minkum), dan tidak boleh ada pihak yang menzalimi atau dizalimi.

Seharusnya jika masyarakat Indonesia yang mayoritas beragama Islam menerapkan nilai-nilai spiritual yang terkandung dalam prinsip-prinsip syariah di sistem pertanian dan perekonomiannya bukan hal mustahil suatu kesejahteraan akan tercapai termasuk dalam hal pertanian. Karena Allah SWT telah berkalikali berfirman didalam Al-Quran untuk 
menjauhi laranganNya dan melaksanakan perintahNya. Seperti dalam firman Allah SWT QS. Al-A'raf ayat 96:

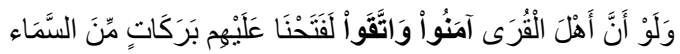

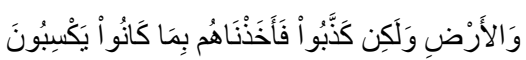

Walavanna ahlaqura amanuu wattaqwa lafatakhnaa 'alaihim barakatim minassamaa a wal ardho walakina kadzabuu faakhodznaa bimaa kanuu yaksibuuna

Artinya : "Jika sekiranya penduduk negerinegeri beriman dan bertakwa, pastilah Kami akan melimpahkan kepada mereka berkah dari langit dan bumi. (Tetapi) mereka mendustakan (ayat-ayat Kami) itu, maka Kami siksa mereka disebabkan perbuatannya." (QS al-A'râf [7]: 96)

Sebagai balasan Allah SWT telah menjanjikan surga dan kehidupan layak di dunia bagi orang-orang yang taat kepadaNya. Selain itu, juga telah dicontohkan dalam kehidupan Rasulullah SAW yang menerapkan prinsip-prinsip syariah dalam kehidupan bertani dan berekonomi. Dimana kesejahteraan dapat dirasakan akibat penerapan prinsip-prinsip syariah.

Hal ini menjadi tinjauan penulis dalam masyarakat petani di Indonesia khususnya dilingkungan pedesaan. Yaitu adanya sistem pengelolaan lahan pertanian dengan cara bekerjasama antar petani yang tergolong unik dan berlangsung secara turun temurun. Hal ini yang menjadi alasan bagi penulis untuk melakukan penelitian tentang mekanisme kontrak kerjasama pengelolaan lahan pertanian pada masyarakat petani di lingkungan pedesaan dan bagaimana tinjauan prinsip-prinsip syariah terhadap mekanisme tersebut. Apakah sistem kerjasama penggarapan lahan pertanian tersebut sudah sesuai dengan prinsipprinsip syariah atau belum.

Disini penulis memilih objek
penelitian di desa Temu, Kanor, Bojonegoro. Desa Temu berjarak $25 \mathrm{~km}$ dari kota Bojonegoro. Wilayah Desa Temu ini berada didekat bantaran sungai Bengawan Solo. Jika musim kemarau wilayah ini termasuk penghasil padi terbesar di Kabupaten Bojonegoro dan jika musim hujan justru banjir akibat luapan sungai Bengawan solo selalu membayangi dan berdampak pada gagalnya panen. Masyarakat didesa ini masih memegang teguh prinsip adat istiadat padahal secara umum mayoritas masyarakat di desa ini beragama Islam. Baik itu dalam kehidupan sehari-hari sampai sistem bercocok tanam masih menggunakan cara-cara tradisional. Dan secara garis umum masyarakat didesa ini masih banyak yang berada dibawah garis kemiskinan. Untuk itu penulis ingin meneliti apakah prinsip-prinsip adat istiadat tentang kerjasama penggelolaan lahan tersebut tidak berbenturan dengan prinsip-prinsip syariah? Dan bagaimana dampak prinsip-prinsip adat tentang kerjasama pengelolaan lahan pertanian 
tersebut dengan kesejahteraan para petani di Desa Temu?

\section{Rumusan Masalah}

Dari latar belakang yang tertulis diatas dan agar dalam penelitian ini tidak terjadi kerancuan, maka peneliti akan menentukan batasan dan merumuskan permasalahan yang akan di angkat dalam penelitian ini adalah bagaimana pandangan Islam terhadap mekanisme kontrak pengelolaan lahan pertanian (sawah) di desa Temu, kecamatan Kanor, kabupaten Bojonegoro?

\section{LANDASAN TEORI}

Petani menurut Kamus Besar Bahasa Indonesia (1991: 1008) adalah orang yang pekerjaannya bercocok tanam. Menurut Sukino (2013:8), pengertian petani adalah seseorang yang bergerak di bidang bisnis pertanian utamanya dengan cara melakukan pengelolaan tanah dengan tujuan untuk menumbuhkan dan memelihara tanaman seperti padi, bunga, buah dan lain lain, dengan harapan untuk memperoleh hasil dari tanaman tersebut untuk di gunakan sendiri ataupun menjualnya kepada orang lain.

Pengertian pertanian menurut Tohir(2006:3) adalah suatu usaha yang meliputi bidang-bidang seperti bercocok tanam (pertanian dalam arti sempit), perikanan, peternakan, perkebunan, kehutanan, pengelolaan hasil bumi dan pemasaran hasil bumi (pertanian dalam arti luas). Dimana zat - zat atau bahan bahan anorganis dengan bantuan tumbuhan dan hewan yang bersifat reproduktif dan usaha pelestariannya.

Pertanian sebagai suatu sistem keruangan yang merupakan perpaduan antara sub sistem fisis dan subsistem manusia. Yang termasuk kedalam sub sistem fisis yaitu tanah, iklim, hidrologi, topografi dengan proses alamiahnya. Sedangkan yang termasuk pada sub sistem manusia antara lain tenaga kerja, kemampuan ekonomi, serta kondisi politik daerah setempat.

(Suhartono 2002: 21)Pertanian di Indonesia memiliki ciri-ciri sebagai berikut:

1. Hak milik lahan pertanian para petani umumnya sempit kurang dari $0,5 \mathrm{Ha}$.

2. Pengolahan tanah di daerah yang padat penduduknya dilakukan secara intensif sedangkan di daerah yang jarang penduduknya dilakukan secara ekstensif.

3. Merupakan pertanian sub sisten dengan modal yang kecil serta alat dan sistem pertanian yang masih sederhana.

Menurut Hanafie (2010: 83-84), Pertanian merupakan proses produksi yang didasarkan atas pertumbuhan tanaman dan hewan. Terlaksananya proses tersebut dalam mencapai pengembangan pertanian sangat tergantung pada peranan sumber daya manusia sebagai pelaksananya. Dalam 
bidang pertanian, bentuk usaha pertanian didominasi oleh pertanian rakyat. Dengan demikian, peranan sumber daya manusia sebagai produsen dapat ditinjau dalam 3 aspek, yaitu:

1. Petani sebagai pekerja usaha tani (cultivator)

Peranan utama petani
dalam usaha taninya adalah
sebagai pekerja, yaitu petani itu
sendiri yang mengusahakan usaha
taninya. Dalam pelaksanaannya,
petani itu tidak bekerja seorang diri,
tetapi dibantu oleh tenaga kerja
lainnya - istri dan anak-anaknya.
Anak-anak yang berumur di atas 10 tahun sudah dapat dianggap sebagai tenaga kerja yang produktif. Mereka dapat membantu mengatur pengairan, menuai padi, mengangkut bibit, dan sebagainya. Tenaga kerja yang berasal dari keluarga petani itu merupakan sumbangan keluarga pada produksi pertanian secara keseluruhan dan tidak dinilai dalam bentuk vang. Seringkali petani juga harus menyewa tenaga kerja dari luar ketika pekerjaan di usaha tani membutuhkan banyak tenaga kerja, sementara tenaga kerja keluarga tidak mencukupi.

2. Petani sebagai pemimpin usaha tani (manager)
Peranan lain petani adalah sebagai pemimpin atau pengelola usaha tani. Dalam peranan ini, sangat diutamakan keterampilan, termasuk keterampilan dalam mengambil keputusan dari berbagai alternatif yang ada. Keputusan yang diambil oleh petani selaku pengelola, antara lain menentukan pilihan tanaman apa yang mungkin dapat ditanam, kapan mulai menanam, kapan pemupukan harus dilakukan, dimana membeli pupuk, berapa dosis pupuk yang harus diberikan, dan lain-lain. Sejalan dengan kemajuan pertanian, petani harus lebih banyak lagi mengembangkan kecakapannya pada proses jual-beli, misalnya menentukan membeli bibit unggul, pupuk, atau alat pertanian baru. Dengan beralihnya pertanian dari sifat subsisten menjadi lebih komersial, tugas petani sebagai pemimpin usaha tani menjadi lebih sulit.

3. Petani sebagai diri pribadi (person)

Petani sebagai pribadi merupakan anggota sebuah keluarga dan ia pun menjadi anggota masyarakat suatu desa atau rukun tetangga. Sebagai manusia, peranan petani sama saja dengan peranan anggota masyarakat lainnya, karena pada 
dasarnya petani itu sama dengan semua manusia pada umumnya yang memiliki 4 kapasitas penting dalam hidupnya, yaitu bekerja, belajar, berpikir kreatif, dan bercita-cita. Petani memiliki kesanggupan dasar yang sama, serta mereka digerakkan oleh dorongan pribadi dan pengaruh masyarakat yang sama pula.

(Antonio, 2004:82)

mendefinisikan

muzara'ah adalah kerja sama pengolahan pertanian antara pemilik tanah dan penggarap, dimana pemilik lahan memberikan lahan pertanian kepada si penggarap untuk ditanami dan dipelihara dengan imbalan bagian tertentu (presentase) dari hasil panen .Almuzara'ah sering diidentifikasikan dengan mukhabarah .diantara keduanya terdapat sedikit perbedaan sebagai berikut: muzara'ah; benih dari pemilik lahan, sedang mukhabarah benih dari penggarap.

(Sudarsono, 2005:43)mengemukakan muzara'ah adalah kerja sama antara pemilik tanah dengan pemilik benih untuk mengolah tanah pertanian atau lading atau sawah, sedangkan benihnya dari petani kemudian diadakan persetujuan bersama yang diatur dalam bagi hasil. sedang mukhabarah adalah memperkerjakan seseorang pada tanahnya dengan diberi upah tertentu (setengah, sepertiga, seperempat) dari penghasilah pertanian kelak, serta bibit dari yang mengerjakan tanah (penggarap/amil).

Dasar hukum Muzara'ah terdapat dalam Al-Qur'an dan Hadist, dalam Al-Qur'an terdapat dalam :

Surat al-Baqarah ayat 267 :

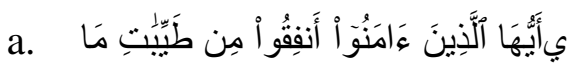

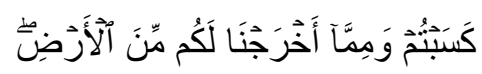

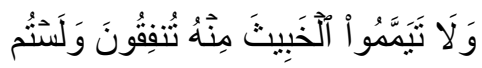

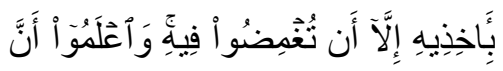

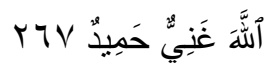

Ya ayyuha alladzina amanuu anfiquu min tayyibati ma kasabtum wamimma akhrajna lakum minal ardi wala tayammamu alkhabitsa minhu tunfiquuna walastum biakhidzihi illa an tughmidhu fiihi wa'lamu anna Allaha ghaniyyun khamiidun (267)

Hai orang-orang yang beriman, nafkahkanlah (di jalan allah) sebagian dari hasil usahamu yang baik-baik dan sebagian dari apa yang Kami keluarkan dari bumi untuk kamu. Dan janganlah kamu memilih yang buruk-buruk lalu kamu menafkahkan daripadanya, padahal kamu sendiri tidak mau mengambilnya melainkan dengan memincingkan mata terhadapnya. Dan ketahuilah, bahwa Allah Maha Kaya lagi Maha Terpuji(QS. AlBaqarah : 267).

QS. Al-maidah ayat 2:

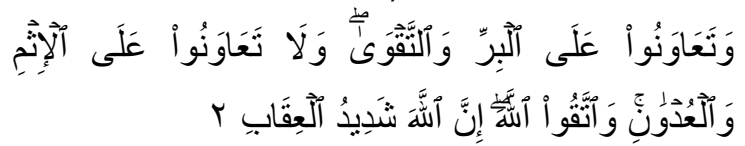


Wata'awanu 'alalbirri waattaqwa wala ta'awanu 'alal ithmi waal'udwani wattaqu Allaha inna Allaha shadiidul'iqabi Artinya :Dan tolong-menolonglah kamu dalam (mengerjakan) kebajikan dan takwa, dan jangan tolong-menolong dalam berbuat dosa dan pelanggaran. Dan bertakwalah kamu kepada Allah, sesungguhnya Allah amat berat siksaNya.(QS. Al-maidah:2)

Sedang dalam hadits Diriwayatkan oleh Muslim dari Thawus ra.

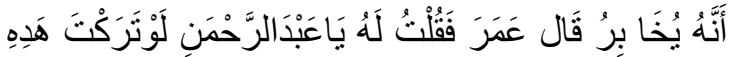

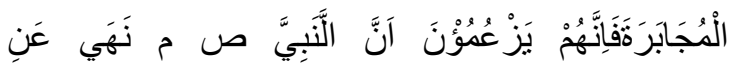

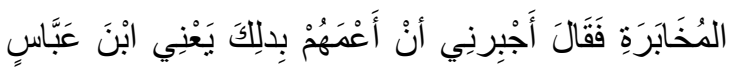

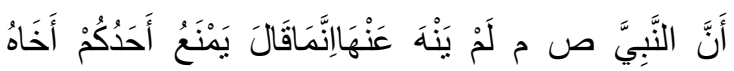

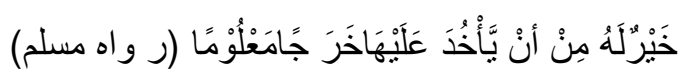

Annahu yukhobiru qala 'amara faqultulahu ya'abdarrahmani lautarakta hadihilmujaabarata fainnahum yaz'umuuna annannabiyya naha 'anilmukhabarari faqala akhbirniy an a'mahum bidzalika ya'niybna 'abbasi annanabiyya lam yanha 'anhaa immama qala yamna'u ahadukum akhahu khairulahu min ayyakkhuda 'alaihaa kharajan ma'luuman

Sesungguhnya Thawus ra. Bermukhabarah, Umar ra. berkata; dan aku berkata kepadanya; ya Abdurrahman, kalau engkau tinggalkan, mukhabarah ini, nanti mereka mengatakan bahwa Nabi saw melarangnya. Kemudian Thawus berkata; telah menceritakan kepadaku orang yang sungguh-sungguh mengetahui hal ini, yaitu Ibnu Abbas, bahwa Nabi saw. Tidak melarang mukhabarah, hanya Beliau berkata, bila seseorang memberi manfaat kepada saudaranya, hal itu lebih baik daripada mengambil manfaat dari saudaranya dengan yang telah dimaklumi.(HR. Muslim)

Adapun syarat-syarat muzara'ah menurut sahabat Umar bin Khattab r.a. adalah :

a) Muzara'ah adalah sebuah transaksi (akad). Jadi, juga disyaratkan adanya dua orang yang melakukan transaksi sebagaimana juga disyaratkan dalam jual-beli.

b) Tidak ada kebodohan di tempat akad, maksudnya tanaman dan tanahnya diketahui agar tidak menimbulkan perselisihan.

c) Hendaknya bagian untuk pekerjanya jelas dari yang akan dihasilkan, seperti 1/3, 1/4.

d) Tidak mensyaratkan adanya batas waktu dalam muzara'ah.

e) Boleh diadakan syarat bahwa bijinya dari si pekerja, sebagaimana boleh disyaratkan bijinya dari pemilik tanah.

Rukun muzara'ah dalam Islam sebagaimana syarat-syarat muzara'ah yang telah dijelaskan, didalamnya juga terdapat perbedaan antara Ahli Figh. Jumhur Ulama yang membolehkan akad muzara'ah, mengemukakan rukun-rukun muzara'ah adalah sebagai berikut : 
JESTT Vol. 2 No. 11 November 2015
a. Pemilik lahan
b. Petani penggarap
c. Obyek muzara'ah, yaitu antara manfaat lahan dan hasil kerja petani penggarap (hasil yang diperoleh sebagai keuntungan).

d. ljab (ungkapan penyerahan lahan dari pemilik tanah dan qabul (pernyataan menerima lahan untuk diolah dari petani).

Adat menurut arti bahasa adalah cara (kelakuan dan sebagainya) yang sudah menjadi kebiasaan. Sedangkan adat istiadat adalah tata kelakuan yang kekal dan turun-temurun dari generasi satu ke generasi lain sebagai warisan, sehingga kuat integrasinya dengan pola perilaku masyarakat.(KBBI:1994)

Adapun menurut istilah agama, para Ulama berbeda ungkapan dalam mendefinisikan adat. Diantara definisi yang mereka sebutkan adalah, "Perkara yang terulang-ulang dan dapat diterima oleh akal dan fitrah yang sehat" (mu'jam Maqayisil). Jadi, menurut istilah agama, tidak semua perkara yang terulang-ulang disebut adat, tapi harus bisa diterima fitrah dan akal sehat.

Kata "Urf secara etimologi berarti " sesuatu yang di pandang baik dan diterima oleh akal sehat" sedangkan secara terminology, seperti yang dikemukakan oleh Abdul -karim Zaidah, istilah 'Urf berarti :Sesuastu yang tidak asing lagi bagi suatu masyarakat karena telah menjadi kebiasaan dan menyatu dengan kehidupan mereka baik berupa perbuatan atau perkataan. (Efendi :2005)

Dasar Hukum 'Urf adalah Surat ala'raf ayat 199:

Jadilah engakau pemaaf dan suruhlah orang mengerjakan yang ma'ruf (al-'urfi), serta berpalinglah dari orang-orang yang bodoh. (QS. Al-A'raf :199)

Kata al-'Urf dalam ayat tersebut, dimana umat manusia disuruh mengerjakannya, oleh Ulama Ushul fiqih dipahami sebagai sesuatu yang baik dan telah menjadi kebiasaan masyarakat. Berdasarkan itu maka ayat tersebut dipahami sebagai perintah untuk mengerjakan sesuatu yang telah dianggap baik sehingga telah menjadi tradisi dalam suatu masyarakat.

Hadits riwayat Abu Dâwud (no. 3569) :

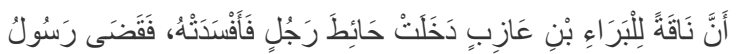

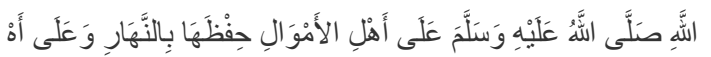

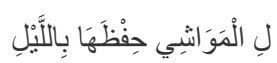

Bahwasanya unta al-Bara' bin 'Azib Radhiyallahu anhu masuk kebun seseorang dan merusaknya. Lalu Rasûlullâh Shallallahu 'alaihi wa sallam menetapkan hukuman bahwa pemilik kebun wajib menjaga kebunnya di siang hari, dan apa yang dirusak unta di malam hari menjadi tanggungan pemilik unta. [Hadits ini dihukumi shahih oleh al-Albâni † dalam Shahîh Sunan Ibnu Mâjah no. 2332] Rasûlullâh Shallallahu 'alaihi wa sallam melandaskan hukum Beliau Shallallahu 'alaihi wa sallam ini pada kebiasaan yang 
umum berlaku bahwa pemilik ternak melepaskan ternak mereka di siang hari dan tidak melepasnya di waktu malam. Sedangkan pemilik kebun biasanya berada di kebun pada siang hari saja. Maka barangsiapa menyelisihi kebiasaan ini, berarti ia teleh teledor dalam menjaga hak miliknya, sehingga laksana orang yang menyimpan hartanya di tengah jalan, maka orang yang mencurinya tidak dikenai potong tangan. Ini menunjukkan bahwa 'urf diperhitungkan dalam penetapan hukum ini. (Ma'alim as-sunan 2/241)

Pada dasarnya, syariat Islam dari masa awal banyak menampung dan mengakui adat atau tradisi itu tidak bertentangan dengan Al-Qur'an dan Sunnah Rasulullah. Kedatangan Islam bukan menghapuskan sama sekali tradisi yang telah menyatu dengan masyrakat. Tetapi secara selektif ada yang diakui dan dilestarikan serta ada pula yang dihapuskan. Misal adat kebiasaan yang diakui, kerja sama dagang dengan cara berbagi untung (almudarabah). Praktik seperti ini telah berkembang di bangsa Arab sebelum Islam. Berdasarkan kenyataan ini, para Ulama menyimpulkan bahwa adat istiadat yang baik secara sah dapat dijadikan landasan hukum, bilamana memenuhi beberapa persyaratan.

Para Ulama Ushul menyatakan bahwa sutau 'urf baru dapat dijadikan sebagai salah satu dalil dalam menetapkan hukum Syara' apabila memenuhi sayarat-syarat sebagai berikut:
1. 'Urf itu harus berlaku secara umum dalam mayoritas kalangan masyarakat dan keberlakuannya dianut oleh mayoritas masyarakat tersebut, baik itu 'urf dalam bentuk praktek, perkataan, umum dan khusus.

2. Urf itu memang telah memasyarakat sebelumnya.

3. 'Urf tidak bertentangan dengan apa yang diungkapkan secara jelas dalam suatu transaksi. Seperti apabila dalam suatu transaksi dikatakan secara jelas bahwa si pembeli akan membayar vang kirim barang, sementara'urf yang berlaku adalah si penjuallah yang menanggung ongkos kirim, maka dalam kasus seperti 'urf tidak berlaku.

4. 'Urf tidak bertentang dengan nash, sehingga menyebabkan hukum yang dikandung nash tersebut tidak bisa diterapkan. 'Urf seperti ini tidak dapat dijadikan dalil syara' karena kehujjahan 'urf baru bisa diterima apabila tidak ada nash yang mengandung hukum permasalahan yang dihadapi.

Para valama ushul figh sepakat bahwa 'urf al-shahih, yaitu "urf yang tidak bertentangan dengan syara'. Baik yang menyangkut dengan 'urf al-'am dan 'urf al-khas, maupun yang berkaitan dengan 'urf al-lafzhi dan 'urf al-'amali, dapat dijkadikan hujjah dalam menetapkan hokum syara'. (Satria Efendi:2005)

\section{METODE PENELITIAN}


Pendekatan Penelitian

Penelitian ini menggunakan pendekatan kualitatif Diskriptif. Yin (2009:1) menjelaskan studi kasus merupakan strategi yang lebih cocok bila pokok pertanyaan suatu penelitian berkenaan dengan how atau why.

\section{Ruang lingkup Penelitian}

Ruang lingkup penelitian terbatas memfokuskan pada para petani muslim di Desa Temu, Kanor, Bojonegoro yang selama masih menjalankan prinsip-prinsip kehidupan berdasarkan kebiasaan atau adat istiadat.

\section{Jenis dan Sumber Data}

Jenis data yang digunakan dalam penelitian ini adalah data primer. Data primer merupakan data utama yang berasal dari hasil wawancara mendalam dan observasi langsung di lapangan.

\section{Teknik Keabsahan Data}

Triangulasi data menurut Moleong (2005:330) adalah teknik pemeriksaan keabsahan data yang memanfaatkan yang lain. Peneliti menyimpulkan bahwa dalam meneliti dibutuhkan keabsahan agar penelitian tersebut dapat dipercaya kredibilitasnya. Penulis menggunakan triangulasi sumber karena penelitian tidak bisa diratakan seperti dalam penelitian kuantitatif, tetapi dideskripsikan, dikategorisasikan, mana pandangan yang sama, yang berbeda dan mana yang spesifik dari ketiga sumber data tersebut. Data yang telah dianalisis oleh peneliti sehingga menghasilkan suatu kesimpulan, selanjutnya dimintakan kesepakatan dengan ketiga sumber data tersebut.

\section{Teknik Analisis Data}

Analisis model Miles dan Huberman (Iskandar, 2009:139-142), dapat dilakukan melalui langkah-langkah sebagai berikut:

1. Reduksi data

2. Display atau penyajian data

3. Mengambil kesimpulan lalu diverifikasi

\section{HASIL DAN PEMBAHASAN}

Desa Temu berada di Kecamatan Kanor, Kabupaten Bojonegoro, Provinsi Jawa Timur. Desa ini berjarak sekitar 30 Kilometer dari Kota Bojonegoro dan 5 Kilometer dari pusat Kecamatan Kanor. Batas Desa Temu di sebelah barat berbatasan dengan Desa Prigi, sebelah selatan berbatasan dengan Desa Simorejo, sebelah utara berbatasan dengan Desa Gedongarum, dan sebelah timur berbatasan dengan Kecamatan Burno. Dalam Profil Desa Temu (2014), disebutkan bahwa Desa Temu memiliki luas lahan persawahan mencapai 754 ha. Mata pencaharian pokok mayoritas penduduk di Desa Temu adalah petani. Jumlah total penduduk di Desa Temu mencapai 6.088 (total laki-laki dan perempuan), dengan pemeluk agama mayoritas Islam sebanyak 6.084 (total lakilaki dan perempuan). Dari total Kepala Keluarga di Desa Temu 32\% masih berada di garis kemiskinan. Karena mayoritas petani di Desa Temu merupakan buruh 
tani dengan lahan kurang dari 0,5 ha tiap Kepala Kelvarga.

Desa Temu terbagi menjadi tiga perdukuhan yaitu dukuh Manding, dukuh Temu dan dukuh Ndono. Sebagian besar lahan pertanian di Desa Temu diairi oleh Arial Irigasi yang berasal dari sungai Bengawan Solo. Dikarenakan letak Desa Temu hanya berjarak 2 Kilometer dari bantaran sungai Bengawan Solo. Hal ini juga menyebabkan wilayah Desa Temu masuk kedalam Peta Rawan Bencana Banjir Kabupaten Bojonegoro.

sistem atau cara kerjasama penggarapan lahan pertanian yang dijalankan oleh sebagian besar para petani di Desa Temu adalah sistem atau cara paron dan sebagian kecil menggunakan sistem atau cara nelon.

Sistem atau cara kerjasma penggarapan lahan pertanian paron adalah pemilik lahan menyerahkan lahan pertaniannya kepada penggarap untuk dikerjakan dalam bercocok tanam dengan ketentuan seluruh biaya operasional selama masa tanam akan ditanggung oleh penggarap, hasil panen akan dibagi dua sama besar antara pemilik lahan dengan penggarap setelah sebelumnya dikurangi $1 / 6$ bagian untuk biaya irigasi, dan jika terjadi kerugian akan ditanggung oleh penggarap.

Sistem atau cara kerjasama penggarapan lahan pertanian nelon adalah pemilik lahan menyerahkan lahan miliknya kepada penggarap untuk dikerjakan, biaya operasional selama masa tanam ditanggung pihak ketiga. Hasil panen akan dibagi tiga sama besar antara pemilik lahan, pihak ketiga, dan penggarap setelah sebelumnya dikurangi 1/6 bagian untuk biaya irigasi. Ketika terjadi kerugian akan ditanggung oleh pihak ketiga dan penggarap.

Terdapat beberapa perbedaan terkait penanggungan kerugian dalam sistem paron dan nelon menurut penjelasan ketujuh informan. Aturan sebenarnya dalam sistem kerjasama paron jika terjadi kerugian maka akan ditanggung oleh penggarap. Tetapi jika kerjasama paron tersebut antara pemilik lahan dan penggarap masih terikat saudara atau kerabat maka pemilik lahan akan turut serta menanggung sebagian kerugian yang terjadi.

cara kerjasama penggarapan lahan pertanian yang dijalankan para petani di Desa Temu merupakan cara kerjasama yang telah turun-temurun dan cara yang umum dilingkungan petani Desa Temu serta cara tersebut mudah untuk dilaksanakan baik ketentuan maupun pelaksanaannya. Karena telah menjadi kebiasaan sejak lama dilingkungan para petani sehingga akan sulit untuk berubah.

Kesesuaian cara kerjasama penggarapan lahan pertanian yang dilakukan para petani di Desa Temu dengan cara kerjasama penggarapan lahan pertanian dalam kaedah fiqh muamalah 
Secara definisi, sistem atau cara penggarapan lahan pertanian paron yang dilakukan oleh para petani di Desa Temu tergolong dalam akad mukhabarah dalam kaedah Islam fiqh muamalah. Hal ini mengacu pada ketentuan sistem atau cara kerjasama penggarapan lahan pertanian paron yang dilakukan para petani di Desa Temu bahwa ketentuan bibit dan biaya operasional saat proses tanam menjadi tanggungan penggarap. Ketentuan-ketentuan dalam proses kerjasama penggarapan lahan pertanian yang dilakukan para petani di Desa Temu telah sesuai dengan syarat dan rukun akad mukhabarah sehingga suatu akad proses kerjasama penggarapan lahan pertanian dinyatakan SAH.

Untuk ketentuan biaya irigasi yang bersifat wajib dan harus dibayarkan oleh setiap lahan pertanian yang diairi Induk Arial Irigasi yaitu 1/6 bagian dari seluruh hasil panen juga termasuk SAH. Karena ketentuan $1 / 6$ bagian dari seluruh hasil panen tersebut merupakan sebuah kesepakatan bersama seluruh petani di Desa Temu. Berikut dalil tentang bermusyawarah:

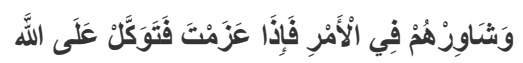

Wasaawirhum fil amri faidza 'azamta fatawakal 'alallah
}

Dan bermusyawarahlah dengan mereka dalam urusan itu. Kemudian apabila kamu telah membulatkan tekad, maka bertawakalah kepada Allah. (QS. Ali Imran [3]: 159)
Terkait ketentuan jika terjadi kerugian dan penggarap yang harus menanggung kerugian dalam proses kerjasama penggarapan lahan pertanian di Desa Temu. Dalam akad mukhabarah dimana pembagian keuntungan dan kerugian harus ditentukan diawal dengan jelas, dan tidak memberatkan salah satu pihak. Melihat hal tersebut dan penjelasan dari informan terkait penanggungan kerugian yang sedikit memberatkan penggarap, maka seakan sistem kerjasama penggarapan lahan pertanian yang dilakukan para petani di Desa Temu menjadi tidak sah. Tetapi disisi lain hal tersebut sudah menjadi hal yang umum sering dilakukan dan menjadi suatu kebiasaan yang dianggap wajar dan tidak dipermasalahkan dilingkungan para petani di Desa Temu. Dalam hal ini peneliti melihat dari sudut pandang kebiasaan atau 'Urf yang menjadi sebuah dasar hukum.

Secara terminology urfadalah sesuatu yang telah dikenal oleh orang banyak dan telah dilakukan berulang-ulang sehingga menjadi tradisi (kebiasaan) mereka, baik berupa perkataan atau perbuatan.(Khalaf:1994)

Urf tersebut terbentuk dari saling pengertian orang banyak, sekalipun mereka berlainan stratifikasi (kalangan awam dan elite) sosial mereka.

Urf berbeda dengan ijma', karena ijma' terbentuk dari kesepakatan para mujtahid. Apabila urf ditentang oleh sebagian kelompok maka tidaklah hal tersebut 
membatalkan kedudukan dari urf, tetapi jika ijma' tidak disepakati oleh salah satu mujtahid maka hal tersebut membatalkan kedudukan ijma. (Djazuli:2010)

Jumantoro (2000) Para ulama, ushul fiqih menyatakan bahwa urf dapat dijadikan sebagai salah satu dalil dalam menerapkan hukum syara', jika memenuhi syarat sebagai berikut:

1. Urf berlaku secara umum, artinya „urf itu berlaku dalam mayoritas kasus yang terjadi di tengah-tengah masyarakat dan keberlakuannya dianut oleh mayoritas masyarakat.

2. Urf telah memasyarakat ketika persoalan yang akan ditetapkan hukumnya itu muncul. Artinya, urf yang akan dijadikan sandaran hukum itu lebih dahulu ada sebelum kasus yang akan ditetapkan hukumnya.

3. Urf tidak bertentangan dengan yang diungkapkan secara jelas dalam suatu transaksi. Artinya, dalam suatu transaksi apabila kedua belah pihak telah menentukan secara jelas hal-hal yang harus dilakukan.

Dari penjelasan tentang 'Urf atau kebiasaan tersebut maka ketentuan kerugian menjadi tanggungan penggarap dalam proses kerjasama penggarapan lahan pertanian yang dilakukan para petani di Desa Temu tersebut tidak menjadi persoalan untuk sahnya proses kerjasama pengarapan lahan pertanian yang dilakukan para petani di Desa Temu. Dengan begitu maka proses kerjasama penggarapan lahan pertanian di Desa Temu tidak bertentangan dengan kaedah figh muamalah.

Terkait terjadinya kerugian yang ditanggung penggarap dalam proses kerjasama penggarapan lahan pertanian yang memberatkan penggarap. Menjadi tugas tokoh agama setempat untuk memberikan pengertian kepada para pemilik lahan dan mengajak seluruh petani untuk mengubah secara pelanpelan adat atau kebiasaan yang menentukan jika terjadinya kerugian akan ditanggung penggarap menjadi ketentuan jika terjadinya kerugian akan ditanggung bersama-sama dengan ketentuan yang telah di sepakati antara pihak yang terlibat dalam proses kerjasama penggarapan lahan pertanian tersebut demi kemaslahatan bersama. Hal ini telah didukung dengan adanya sebagian petani telah menggunakan ketentuan bahwa jika terjadi kerugian akan ditanggung bersama sesuai persentase kesepakatannya atau adanya ketentuan yang dilakukan para pemilik lahan jika terjadi kerugian maka akan turut serta menanggung sebagian biaya operasional pada proses tanam berikutnya.

\section{Keterbatasan Penelitian}

Keterbatasan informan dalam penelitian ini merujuk pada proses pengumpulan data informan yang mengalami kesulitan karena data dari informan sangat terbatas, serta informan 
memiliki keterbatasan latar belakang pendidikan, sehingga data yang digali belum cukup memberikan informasi lengkap terkait dengan penelitian ini.

Penelitian ini hanya dapat menyimpulkan secara umum dan garis besarnya saja terkait sistem atau cara kerjasama penggarapan lahan pertanian yang dilakukan para petani berdasarkan dengan kebiasaan yang telah mengakar sejak lama dan tinjauan kaedah Islam dalam mengatur cara kerjasama penggarapan lahan pertanian terkait praktek cara kerjasama penggarapan lahan pertanian yang dilakukan oleh para petani di Desa Temu tersebut, serta dampak positif dan negatif yang dirasakan setiap pelaku dalam praktek kerjasama penggarapan lahan pertanian tersebut. Hal tersebut dikarenakan peneliti terkendala untuk menggali informasi lebih mendalam sebab kondisi sabagian besar para informan memiliki keterbatasan pendidikan dan cenderung tidak mau menjelaskan jawaban secara rinci.

\section{SIMPULAN}

Sitem atau cara kerjasama penggarapan lahan pertanian yang dilaksanakan para petani di Desa Temu, Kecamatan Kanor, Bojonegoro adalah sistem atau cara maron dan sebagian kecil nelon.

Dalam kesesuaian sistem atau cara kerjasama penggarapan lahan pertanian yang dilakukan para petani di Desa Temu dengan kaedah Islam fiqh muamalah, bahwasannya sistem atau cara kerjasama penggarapan lahan pertanian yang dilakukan para petani di Desa Temu tidak bertentangan dan sesuai dengan kaedah figh muamalah yang mengatur tentang kerjasama penggarapan lahan pertanian. Proses kerjasama penggarapan lahan yang dilakukan para petani di Desa Temu dapat dikategorikan sebagai kerjasama yang sah, karena telah memenuhi rukun dan syarat yang berlaku serta kedua belah pihak saling mengandung prinsip muamalah yaitu adanya unsur saling rela dan saling adanya manfaat yang diperoleh, serta merupakan adat kebiasaan ('urf) yang tidak bertentangan dengan nash Al-Qur'an dan Hadits serta tidak mengandung madharat. Dan dilakukannya atas dasar kesepakatan dan kerelaan dari pemilik tanah dan penggarap sedangkan mereka sendiri ('aqid) menerima dengan lapang dada, maka muamalah itu sah dan dibolehkan.

Saran yang dapat penulis sampaikan dalam penelitian ini adalah:

1. Bagi petani muslim

Bagi petani muslim, setelah melihat fenomena sebagian besar petani muslim belum mengetahui dan memahami bagaimana agama Islam mengatur proses kerjasama penggarapan lahan pertanian yang diatur dalam kaedah figh muamalah, agar senantiasa terus mempelajari kaedah-kaedah Islam khususnya dibidang bermuamalah, dimana kaedah figh muamalah telah 
terbukti membawa manfaat keadilan serta kemaslahatan bagi setiap pelakunya. Untuk pemilik lahan agar senantiasa lebih peka terhadap pengorbanan para penggarap dalam mencapai hasil panen yang maksimal. Untuk penggarap agar jangan terlalu berkecil hati hanya karena status sosial, jika ada masalah atau sesuatu yang kurung berkenan segera utarakan dengan baik kepada pemilik lahan selaku partner dalam bekerjasama.

\section{Bagi pemerintah}

Diharapkan adanya perhatian lebih termasuk pendampingan dan pengawasan terhadap masyarakat petani di pedesaan terkait mekanisme serta proses penggarapan lahan pertanian sehingga pelaksanaan mekanisme penggarapan lahan pertanian dapat berjalan lancar,maksimal, dan adil terkain pembagian hak dan kewajiban dalam mekanisme penggarapan lahan pertanian. Sehingga tidak ada salah satu pihak yang dirugikan.

\section{Bagi peneliti selanjutnya}

Diharapkan dapat meneliti topik yang lebih mendalam lagi mengenai ekonomi pertanian di pedesaan, kajian-kajian syariah terhadap pola pertanian dan pola perilaku para petani di pedasaan mulai dari proses bertanam sampai pemasaran, manajemen keuangan keluarga petani dan lain-lain yang secara pendidikan dan ilmu pengetahuan masih memiliki keterbatasan. Sehingga dengan banyaknya penelitian-penelitian baru memberi dampak positif terhadap kemajuan dan kemaslahatan masyarakat petani di pedesaan.

\section{DAFTAR PUSTAKA}

Abdillah bin Ismail, Imam, 1992. Shoheh Bukhari, Juz III, Beirut Lebanon: Darul Kutub,

Antonio, syafei, 2004. Figh Muamalah, Bandung: CV Pustaka Setia,

Arikunto, Suharsimi, 1998. Prosedur Penelitian Suatu Pendekatan Praktek, Ed Revisi IV, Jakarta : Rineka Cipta,

Azwar, Saefudin, 1998. Metodologi Penelitian, Cet ke-1,, Yogyakarta : Pustaka Pelajar,

Badan Pusat Statistik (BPS). 2014. www.bps.go.id/ Jumlah dan Persentase Penduduk Miskin di Indonesia 2013.

Depag RI, 2010 Al-Qur'an dan Terjemahnya, Bandung: CV Diponegoro,

Dewi, Gemala dkk, 2005. Hukum Perikatan Islam di Indonesia, Jakarta: Prenada Media,

Djazuli, 2010, Ilmu Fiqih, Jakarta: Fajar Interpratama Offset, hal. 88.

Efendi, Satria, 2005. 'Urf Sebagai Dasar Hukum, Bandung: PT Jayakarta

Hadikusuma, Hilman, 1990. Hukum Perjanjian Adat, Bandung: PT Citra Aditya Bakti,

Hanafie, 1993. Ushul Fiqh, Jakarta: Wijaya, Hanafie, Rita. 2010. Pengantar Ekonomi Pertanian. Yogyakarta: Penerbit Andi 
Haroen, Nasrun, 2007. Fiqh Muamalah, cet. Ke-2, Jakarta: PT. Gaya Media Pratama, Hasby Ash-Syieddieqy, Hasby, 1974. Pengantar Fiqih Muamalah, Jakarta: PT Bulan Bintang,

Khallaf,Abdul Wahab. 1994 Ilmu Ushul Fiqih, Semarang: Dina Utama Semarang,

Moleong, Lexy J, 2010. Metodologi Penelitian Kualitatif. Bandung: PT Remaja Rosdakarya,

Nasrun, Haroen. 2007. Fiqh Muamalah. Jakarta: Gaya Media Pratama

Rahman, Afzalur, 1995. Doktrin Ekonomi Islam, Jilid II, Jogjakarta : PT Dana Bhakti Wakaf,

Rasjid, Sulaiman, 1994. Fiqh Islam, Bandung: Sinar Baru Algensindo,

Sudarsono, 2005. Pokok-pokok Hukum Islam, Jakarta: PT. Rineka Cipta,

Suhartono, 2002. Model Pertanian Indonesia. Jakarta : PT Bakti Mutiara

Suhendi, Hendi, 2002. Fiqh Muamalah, Jakarta : PT Raja Grafindo Persada,

Sukino, 2013. Pertanian Indonesia, Jakarta: CV Abadi Jaya

Sumantoro, Totok, 2000, Kamus IImu Uhsul Fiqih, hlm. 335-336.

Syarifuddin, Amir, 2003. Garis-Garis Besar Fiqh, Bogor: Kencana,

Tim Penyusun Kamus Pusat Pembinaan dan Pengembangan Bahasa. 1991. Kamus Besar Bahasa Indonesia ed.2 cet.3. Jakarta: Balai Pustaka

Tohir, 2006. Perkembangan Pertanian Adat, Jakarta: Penerbit Wira Jaya Yin, 2009. Metodologi Penelitian Kualitatif, Jakarta : PT Pustaka 